\title{
SPEECH GENRES AND DISCOURSE: GENRES STUDY IN DISCOURSE ANALYSIS PARADIGM
}

\author{
Vadim V. Dementyev \\ Saratov State University \\ 83, Astrakhanskaya str., 410012, Saratov, Russia
}

\begin{abstract}
The article is devoted to the place of research on speech genres in the paradigm of discourse analysis. Focus is brought to bear on the directions of discourse analysis which have much in common with the theory of speech genre problems, categorical apparatus or set of base units, as well as using speech genre methodology to solve their problems. It is shown that the main problem, combining discourse analysis and theory of speech genres, is structuring and parameterization of speech communication, and thus - search for basic models of structuring, which organize a production of speech and its interpretation. In this regard, discourse units as well as their location with respect to the genres in the general speech space are discussed. The communicative and cognitive aspects of these units are analyzed, the chain links are constructed, which correspond to the components of communicative concepts that have clear compositional, thematic and stylistic content: the standard structure of the communicative concept is a chain of "action/act process / manner $\sim$ role / type $\sim$ genre $\sim$ communicative tonality", while in most chains the main components are speech genres. Much attention is paid to the discursive classification of speech genres: genres are discussed in different types of discourse.
\end{abstract}

Key words: speech genres theory, discourse analysis, parameterization of speech, classification, communicative concepts

\section{INTRODUCTION}

Modern discourse analysis is based on the concept of speech genre (hereinafter $\mathrm{SG}$ ) as one of the most effective explanatory mechanisms in the process of studying speech generation and interpretation. The theory of speech genres (hereinafter - SGT) is one of the existing practice patterns of verbal communication, considering the situation and sphere of communication, style, intentional factor, form of speech, ways of beginning and ending the speech, initiative transfer in the dialogue, as well as strategies and tactics of communication. This is a favorable difference of speech genre from language units "outside" the situation of communication and from speech acts as elements of this situation.

The history of SGT (about development and current state of SGT in Russia and abroad, see, e.g., in monographs and collective monographs: [Swales 1990; Adamzik 1995; Gatunki mowy 2000-2007; Witosz 2005; Anthology of speech genres 2007; Fix 2008; Dementyev, 2010; Pokrovskaya 2011; Salimovsky 2002; Sherstyanikh 2013], journal "Speech genres") was marked by a number of important achievements - external and internal structure of discourse in statics and dynamics. If we try to characterize the development of speech genres theory in the most general terms, we can say that, firstly, the theory of speech genres is in the process of great changes together with general scientific paradigm in linguistics; however, in almost every new scien- 
tific paradigm SGT is in demand. Secondly, SGT continually contributes to the development of new trends in linguistics, also SG concept is allocated as the basic unit and is one of the basic units of this theoretical concept.

In the late 1970s, when Bakhtin's article "The problem of speech genres" was published in the Soviet Union, the study of speech in linguistic scientific paradigm was determined by:

(1) Soviet/foreign colloquialisms/methodology of conversation analysis (the study of colloquial speech was reflected in a series of monographs "Russian colloquial speech" (Moscow) wherein the Soviet school is characterized by search for particular speech systematicity that is different from the language).

(2) Theory of speech acts: Just as linguists in the West, Russian linguists at this time successfully used the methodology of pragmatics and speech acts theory of J. Austin and J. Searle It had become vital for poststructuralist linguistics to consider the human factor in language components in communicative situations and discourse. At the same time, these studies were carried out through external linguistic means, based on a deep understanding of units and system of relations, or significance of language inherent in the prior - system-structural - scientific paradigm.

It is through the prism of these theories that linguists welcomed M.M. Bakhtin's concept of speech genres: the first attempt of its practical use was a significant convergence of its provisions for colloquialisms and the theory of speech acts. This was significant all the more so because the linguistics of speech was characterized, on the one hand, as a total 'pragmaticalized' scientific apparatus, and on the other - a search for base units, in a formal and more comprehensive relationship exceeding the sentence / speech act (this search leads to an intersection of the general theory of communication, colloquialism, stylistics, pragmatics, text linguistics).

The article by A. Wierzbicka - "Speech Genres" [Wierzbicka 1983], which received wide publicity, reflects precisely this state of speech linguistics. These features were fully appropriate for the next stages of development in speech genres theory.

By the end of the 80 's - early 90 's the ideas of SGT were subjected to further pragmatization; and the method of speech acts theory in genre studies of this time (generistics) started to dominate. As a result, SGT suffered some drawbacks in comparison to TSA (see below).

By the mid-late 90s, with linguistic concepts becoming more semantic and cognitive, speech genre studies also undergo this influence, and the content side of speech genre comes to the fore. The very notion of "genre" largely interacts and intersects with the idea of "concept". It is significant that SG once again becomes (in another sense) a base unit:

(1) of cognitive discourse analysis

(2) for studying communicative competence and communicative concepts,

(3) of national and cultural (language and communicative) world view

(4) for portrying linguistic identity

(5) of Linguo cultural typecasting. 
Further semantisation of scientific research in linguistics was marked, on the one hand, by increasing attention to the content of the language units, and on the other, involvement in the linguistic usage of complex phenomena(manipulation, hint, irony, etc. and aspects of indirect communication), which were not subject to systematic study in linguistics earlier. When studying these phenomena again — in a slightly different form - they are in demand to explain the potency of speech genre model.

Now the concept of SG is one of the most important theoretical representation of pragma linguistics, text linguistics, stylistics, sociolinguistics, psycholinguistics, cultural linguistics (each case of understanding SG has its own adjustments).

In particular, the concept of speech genre is associated with general issues of communicative and speech competence, framing of knowledge [Minsky 1975; Fillmore 1976; Dijk 1985]: cognitive knowledge about SG is organized into conceptual systems, which has recently been actively described in frame terms [Mustajoki 2013; Peeters 2009; Shevchenko, 2015].

In addition, the concept of SG is associated with intranational speech cultures (practical usage of basic SG kit is considered to be the most significant aspect of speech competence, according to V. Goldin and O. Sirotinina - amongst six "international speech cultures" [Goldin, Sirotinina 1993]).

SGT continues to actively develop: description and systematization of speech genres is being carried out consistently and successfully, as also the development of specific meta-language for describing the SG. Various aspects of speech genres are being studied, their number is multiplying: linguistic aspects of $S G$ [Bhatia 2002; Dementyev et al. 2014; Dementyev 2010; Dymarsky 2015]; text features of SG [Tannen 2010; Borisov 2001; Dementyev 2015; Matveev 1995]; stylistic peculiarities of SG [Kozhina 1999; Mkrtychyan 2015; Salimovsky 2002]; psycholinguistic aspects of SG [Sedov 2016; Krasnikh 2015]; cultural aspects of SG [Goddard, Wierzbicka 1997; Dementyev 2009; Lakoff 2006; Manes 1983, 1984 by Thomas; Wierzbicka 1991; 2006; Riabtseva 2007]; speech genres and concepts [Dementyev 2010: 248-258; Slyshkin 2005; Shevchenko 2015]; SG and history [Hanks 2000; Balashova 2014].

At the same time, the main problem combining discourse analysis and theory of speech genres in all phases, remains structuring and parameterization of speech communication, and thus the search for basic models of structuring, which organize speech production and its interpretation continues. Speech genre acts as a constitutive category of discourse and as a unit of discourse.

\section{SPEECH GENRE AS A CONSTITUTIVE CATEGORY OF DISCOURSE}

The notion of genre has always occupied an important place in linguistic concepts of speech system. This problem is not just unresolved, but also has many years of negative experience, due to earlier failures and hesitancy for further research.

The main obstacle on the way to actual linguistic study of genres lies in the nature of its variability. Even if we imagine that someone will make a complete list of SG, in any attempt, it will be almost impossible to apply it to speech and genre variety 
in practice, due to a huge number of small and large deviations from the "standard", "author's" and "listener's" unpredictability, personal attitude, subjective will and other different unpredictable speech components.

Of course, diversity of genres and their variability is not merely a single unresolved problem of SG's place in systematicity. The notion of genre, on the one hand, has acquired a strong position in the theory of discourse (earlier - in linguistic text) as one of its basic units (although it is not acknowledged as the basic unit of discourse genre organization by researchers); on the other hand, many modern works on the theory of discourse/text do not use either the term "genre", nor the ideas of Bakhtin and other ideas existing in Russia "after Bakhtin's" theory of speech genres.

Thus, the problem of speech systematicity is a key issue not only for the theory of speech genres: it would be no exaggeration to say that an adequate solution to this problem is the main task of linguistics of text and discourse theory.

As is known, the basis of text linguistics since its inception on the basis of pragmatics, stylistics and rhetoric lies in the idea of special communication practices, standards and recognizable speech rules, which organizes speech while at the same time, remains different from language rules. In fact, if the "rules of the text/speech" coincided with the language rules and norms, it would be unclear as to what are the differences between various types of texts in the same language (novel, note, protocol, letter) and what the differences will be between the text as a unit of speech and a sentence.

In text linguistics it is proven that "the rules of the text/speech" are multidimensional, variative and addressed to numerous spheres of extralinguistic reality: to the language and language/speech units which make up the text, to the content, i.e. the true or imaginative reality, to the author (to his intentions, motives, i.e., to his purpose) and to the reader/listener, to other authors and texts, and finally, to the culture (in any text "just like a drop of water in the ocean", all of national and humane culture gets reflected).

Of course, the text addresses its own genre as the most obvious from the text rules.

In the context of this discussion, the term "genre" seems intuitively clear and logically related to the text, however, the question that remains unresolved is how to define the genre of work that is devoid of (literary) traditions, for example, "Krokhotok" by A. Solzhenitsyn and"Fallen Leaves" by B. Rozanov (the writers take credit for "invention" of these genres), for example:

- The baby is crying. You get up. After all you are here and not asleep.

- If he cries, then what? He would cry in the arms. Perhaps I'll hold him.

(Why the family breaks up; the first Nadia)

Even more obviously, this applies to abstract, modernist, symbolist, futurist poetry. Compare:

\section{IZRE}

It is an honor to be born a poor man.

-D. Burliuk

These "difficult" cases, however, represent only a stylization of the real difficulties that we find in large numbers in real direct communication. The content complexity, ad- 
ditional interpretive moves of the addressee and the inherent varieties of indirect communication, are not the prerogative of the "difficult" areas of communication. Compare:

(A enters the room where $B$ and $C$ are working)

$A$. Whatever/but it is lunch time //

B. Uh-huh // (A silently gathers and leaves to dine)

(example from: [Kitaygorodskaya, Rozanova, 1999: 360]).

Saying whatever/but it is lunch time can be interpreted as an offer to have dinner together, but this offer is vague. In any case, it is impossible to be sure what is the goal of the speaker, based on follow-up actions of the other participants - A does not try to persuade his colleagues, and, moreover, A is quite satisfied with the vague response Uh-huh. The latter perhaps, proves that expression whatever/but it is lunch time is understood as purely informative (message about unknown information concerning time) and does not contain any inducement. However, the purpose of the first phrase is not clear. As if it has been uttered to make the recipient understand it merely as a remark rather than an offer.

The researcher and linguist, faced with such a material, builds various hypotheses about the replica of this conversation. There is no doubt that the same incongruity exists amongst the participants themselves. Thus, even in this seemingly "simple" everyday conversation there cannot be a "simple" interpretation, that which implies a semiotic use of signs, because, obviously, we have before us indirect communication, where the uncertainty is inherent in the intentions of the speaker, a fact which is understood by the addressee. The response Uh-huh is a definite signal that the specific information has been taken into consideration (lunch time), and there is an indefinite refusal for an indefinite offer.

Understanding of the material (such examples are primarily characteristic of oral communication) lead the linguistics of text in the $60-70$ s to the necessity of using a complex set of text categories (including situational, dialogical, multiple character interpretations, intertextuality, verbal and non-verbal components of communication). Some of these categories which determine the completeness of a work extracted text linguistics from syntax, which deals with means of communication between sentences and very soon formulated linguistics of discourse from traditional text linguistics. "Text plus situation" became its main categories. Interacting with pragmalinguistics and sociolinguistics, linguistics of discourse is enriched with the following categories:

(1) Participants of communication (status-role-playing and situational-communicative characteristics);

(2) Terms of communication (presuppositions, sphere of communication, chronotop, communicative sphere);

(3) Organization of communication (motives, goals and strategies, segmentation, communication control and variability of communicative means);

(4) Means of communication (channel and mode, tone, style and genre of communication).

Language is the main factor in organization and normativity of communication (in synergic terminology — attractors). Except for language, there are a large number 
of different ways to streamline communication, overcome entropy, different genre and rhetorical rules, verbal and non-verbal communication, communication categories.

For understanding genres as a means of formalization of communication it is essential to understand SG as a transition phenomenon between language and speech. On the one hand, genre is not communication, but only its form [Bakhtin 1996: 192]; on the other hand, it is a speech form, although it is already quite standardized. SG is not a language, but also "not quite" speech: it is a transition phenomenon with hybrid properties. Genre is a high level unit, when there are no boundaries between speech and language. Speech genres make up buffer space consisting of "alienated" language system and its actual use. Genres bring systemacy, standard and semiotic beginning into speech and communication [Benveniste 1974], contributing to the development and crystallization of language in the "fight" against the disadvantages of indirect communication and preventing effective exchange with more precise meanings.

Speech genres, representing communication attractors, impose limits on interpretation of speech utterances, thereby making interpretation more standard and reducing the degree of undefined communication [Bogin 1997]. One of the most important SG features is to serve as identification to the addressee of intention. Compare the determination of SG by S. Gajda: this is "horizon of expectations for listening and a model building for speakers" [Gajda 1991: 70]. K. Dolinin indicates the property of SG as a "cognitiveconstructive aspect of SG": "The knowledge of genre canons $<\ldots>$ provides identification of the genre by the recipient (it is often enough to produce a small segment of discourse), i.e. orientation in speech event in which he/she is involved, activation of corresponding script, kept in lasting memory, and, consequently, setting the desired wave, turning on corresponding setting - perceptual or actual, and as a result, the ability to forecast a partner's future speech acts, further unfolding of discourse and adequate reaction" [Dolinin 1999: 10].

Genre speech consistency is made up of the actual speech and genre moments of standardization and formalization (common to all speech genres) and rhetorical moments of formalization (inherent in rhetorical genres in which the sender seeks to "construct a sentence in a more effective way" [Sirotinina 1999: 28]).

The place of speech and rhetorical genres in general structuring of verbal and nonverbal communication is a typology based on the freedom level of a listener's interpretive activities (as has been said, the genres take an important part in limiting this freedom) (Table. 1).

Table 1

\section{Typology of communication according to the degree}

of the listeners freedom of interpretation

\begin{tabular}{|c|c|c|c|c|c|c|}
\hline $\begin{array}{c}\text { Basic } \\
\text { sentence }\end{array}$ & $\begin{array}{l}\text { Nonisosemic } \\
\text { linguistic } \\
\text { construction }\end{array}$ & $\begin{array}{c}\text { Elliptical } \\
\text { construction }\end{array}$ & Tropes & $\begin{array}{l}\text { Conventional } \\
\text { indirect } \\
\text { statements }\end{array}$ & $\begin{array}{l}\text { Flirt, } \\
\text { irony, } \\
\text { small } \\
\text { talk }\end{array}$ & $\begin{array}{c}\text { Unpredictable } \\
\text { interpretation } \\
\text { of a listener }\end{array}$ \\
\hline \multicolumn{2}{|c|}{ Explicit statements } & \multicolumn{5}{|c|}{ Implicit statements } \\
\hline \multicolumn{4}{|c|}{ They are implemented by means of language } & \multicolumn{3}{|c|}{ Language tools are insufficient } \\
\hline \multicolumn{4}{|c|}{ Conventional statements } & \multicolumn{3}{|c|}{ Unconventional indirect statements } \\
\hline \multicolumn{4}{|c|}{ Genre typed statements } & \multicolumn{3}{|c|}{\begin{tabular}{l|l} 
& Genre non-typed statements \\
\end{tabular}} \\
\hline
\end{tabular}


The most important genre aspects of structure and interpretation of communication are:

- Existence of typical genre forms, which result into statements (including indirect ones).

- Existence of variability inside genres; existence of changing accents and secondary genres.

- Existence of indirect speech genres (genre as implicit information).

- Genre as attractor i.e. means of standards and removal of "indirect" communication.

\section{SPEECH GENRE AS A UNIT OF DISCOURSE}

Turning to the units of discourse, we emphasize that different units present different types of systematic discourse in the logic of speech attractors. In general, despite the fact that all researchers recognize speech attractors, it is still impossible to present a full picture of the relation between such moments of systematicity - even if it includes the most widespread model and studied types of rules and regulations, categories, units.

The following is a very rough list that represents different types of systematic discourse - as has been said, almost each of them has some moments of genre systematicity (and some are even equal):

- speech genre, subgenre, hyper genre

- communicative category, communicative concept (and hence communicative value), frame, script

- speech act, illocutionary act, speech/communicative course, illocutive component, intention and intentional state

- strategy (micro and macro strategies), tactics

- speech event, dialogical unity, transaction

- (function) style, tone, discourse type

- connector, "loop"(thematic) chain of theme-rheme progression, functional perspective and communicative dynamism.

As can be seen, the list (for convenience, we split it into several homogeneous groups) includes almost all units and modes, which are used in modern discourse theory - roughly speaking, we have included here everything beyond the level of language syntax and sentence, starting with specific communication means between two sentences in the text.

In some cases, the relationship between individual and group units is carefully examined in linguistics, for example, between intention and intentional state (starting with J. Searle 1983). A number of works is devoted to the relationship between the concepts communicative category and communicative concept [Karasik 2002; Karzenkova, Salimovsky 2005, Shevchenko, 2015]: the category is calibrated/scaled, there is no imaginative component and values are significantly weak.

Let's consider the relationship between speech genre and speech act: a stage in the development of SGT passed under the sign of rapprochement between mutual influence of these theories. 
Bakhtin's theory of speech genres, according to colloquists, is inseparable from speech act theory created by the British logician J. Austin [Austin 1962] (Bakhtin's "statement" defined by the trinity "theme — style — composition", is often identified with the "speech act "of J. Austin).

Genetic closeness of speech genres theory and speech act theory has repeatedly been noted by various researchers [Wierzbicka 1983; Dönninghaus 2001; Kozhina 1999; Mkrtychyan 2015; Fedosyuk 1997; Shmelev 1997].

In 1983 A. Wierzbicka, compared the position of speech acts theory, which was very popular and influential in linguistics of speech, and Bakhtin's theory of speech genres, which was almost unknown to wide linguistic public, and exposed the first theory to heavy criticism. She pointed that even though the aim of SAT is to analyze real units of speech act, in reality it has not freed itself sufficiently from prior scientific paradigm of linguistic limitations and does not go beyond the sentence in speech understanding:

"The point here is not about the terminology change. And it is also not about the opposition of something static to dynamic. "Speech genre", as understood by Bakhtin, is an action, not a product (more precisely, it is a codified form of action). The word "genre" is better, it is less erring than the word "act", because "act" is a short, routine saying. As a result, the study of human speech acts often turns into sentence study - especially the sentences that are specialized as weapon of certain genres. "The fact is that there are types of sentences, which usually function as whole utterances of particular genre types. These are question, exclamation and incentive sentences" [Bakhtin 1996: 194]. <...> The notion of speech genres, formulated and developed in numerous works of Bakhtin, seems to me to be very fruitful for both literary and linguistic studies (as well as for culture study in general). In my opinion the emphasis that Bakhtin lays, on the one hand, on meaning diversity of speech genres, and on the other - the need for unified methodology of their research is very important" [Wierzbicka 1983: 126].

M. Kozhina [1999] formulated the most important differences between speech act and speech genre (i.e., subject and aim of speech act theory and speech genres theory) in a more precise way.

Pointing, like other researchers, to considerable genetic affinity of these theories (the similarities between TSA and TSG are the starting points and definition of the unit under study as a speech; the similarity is also their dynamic aspect: SA and SG as units of linguistic communication process and speech activity as units (elements) in speech dynamics, in the process of constructing the text, discourse; the word as the action and activity of communication; hence the similarity is the principle of studying this unit in the context of extralinguistic factors [same: 54]), the researcher emphasizes that the most important differences lie not in quantity, but in significant qualitative planes - theoretical, methodological, ideological, beginning with a general worldview settings of the creators of these theories: "Existing differences between these concepts are due to specificity of national (or regional), scientific and philosophical interests and aspirations of the founders of these theories; G. Austin and J. Searle on one side, M. Bakhtin on the other [Same: 52].

These are the following lines of differences: 1) SA - action, SG has quantitatively and qualitatively a more complex nature and correlates with situation, event, text; 
2) the focus of TSA is grammar (sentence), TSG is verbal communication and functional style; 3) TSA is monological, TSG is dialogical (sociological) [Same: 18-22].

In our opinion, consistent consideration of the above concepts reveals some obvious similarities and "mutual repulsion": so the similarity between the terms "speech act" and "speech genre" is obvious, as well as techniques to study them. At the same time we pay attention, on the one hand, to apparent diversity of SG and relative homogeneity of SA, on the other hand - SA is not close to all SG (hardly anyone would think to talk about the speech acts of lectures, discussions, conversation). We consider that extended understanding of SG allows the bringing together of SA and SG if the position of the latter is primary; SA especially comes closer (and is even identified) with a type of SG, namely conventional primary simple SG.

Let's now consider another significant problem both for SGT and for discourse such as a group/chain of genre phenomena in speech systematicity. The work of Dementyev [Dementyev 2016] presents a cognitive study of mental images of these phenomena in the minds of native speakers (based on the material surveyed), here the center of attention were communication concepts having a clear composition - thematic stylistic content: the fixed names of these concepts are either the direct names of speech genres, or their components (strategies, tactics, etc.), or they reflect an attitude towards them within a given culture.

Standard structure of communicative concept is a chain of "action/act $\sim$ process/ manner $\sim$ role/type $\sim$ genre $\sim$ tonality".

In the case of symmetric conceptualization all the links in the chain are filled (it is clear that such situations are rare, especially in the case of new and borrowed concepts).

On the forefront can be speech genre typification, action (communication and speech acts), process (communication, speech events and complex events), behavior and role in this type of communication (e.g. competition or game) or social type itself (or rather its communicative refraction - linguo-cultural type).

Correspondingly, the name or type (obviously, it will be a noun) of the speech action can be on the forefront amongst the other names of communicative concepts: single (speech act) and long duration (verbs - perfective and imperfective verbs respectively), name of the process (noun) or genre name (nouns in this function are more common than verbs and are called speech acts).

In this respect, the bigger evaluation units in this evaluation chain are especially significant (and other units may be absent from the assessment point of view), for example, in the evaluation chain (лесть $\sim$ льстить $\sim$ льстеи $\sim$ льстиво/льстивьй) flattery $\sim$ to flatter $\sim$ flatterer $\sim$ in a flattering manner, flattering is the principal component, apparently, in most of these genre, but in one of the newest chains (тролль троллинг троллить) troll $\sim$ trolling $\sim$ to troll, the main component is evaluative type troll; the genre is likely trolling (the genre is perceived as major, although troll is derivationally the source), the tone, apparently exists, but adjective and adverb are absent.

As for specific language processing the chains "genre $\sim$ tone", some of the details have already been revealed in the questionnaire [Dementyev 2016]: one-word names nouns and verbs were on the forefront; adjectives and adverbs were presented very rarely 
(their markedness is obvious), "action / SA (verb) genre name (noun) tonality: 1) genre characteristics (noun $\Rightarrow$ adjective), 2) characteristics of action / SA (verb $\Rightarrow$ adverb).

Apparently, it is possible to take for granted that this genre relevant axiology is fixed at the lexical level, at the same time evaluative tokens are highlighted:

(1) Genre title (noun) = evaluation of the genre (denunciation, flattery, boasting);

(2) verbs - action names / SA (the same, but less expressed (boast, slander, incite);

(3) evaluative characteristics of the genre (actions/act as a part of the genre intragenre strategies and the like.) — adjectives, adverbs: genre performance is assessed in this case:

a) general assessment of SG is preserved and enhanced (the genre is performed correctly): sincere, honest, wise heart talk, imaginative novel;

b) contrary to or opposed to overall evaluation SG (the genre is not properly performed): insincere heart talk, graphomaniac novel.

\section{DISCOURSE CLASSIFICATION OF SPEECH GENRES: GENRES IN DIFFERENT TYPES OF DISCOURSE}

No less obvious is the theoretical and practical connection between the two discussed theories - discourse theory and the theory of speech genres - present in the typological sphere: the division of a certain type of discourse on genres and connection of discursive classification, i.e., allocation of types of discourse on any basis, with speech genre classification. In other words, differentiating respective types of speech genres.

This tradition probably has a very long history: typological discourse models date back to Aristotle's ideas about literary genres, as well as provide them with the same types of oratorical speeches (advisory, epideictic, judicial).

It should be noted that this tradition is actively developing in modern discourse analysis: compare recent research in speech genres in scientific discourse [Salimovskiy 2002; Dönninghaus 2005], political writing [Duskaeva 2012], religious [Bobyreva 2007; Itskovich 2015; Wojtak 2011], political [Lakoff 2001; Sheigal 2004], pedagogic [Oleshkov 2012], medical [Ponomarenko 2011], judicial [Dubrovskaya 2014; Palashevskaya 2012], colloquial [Borisova 2001; Small talk 2000; Tannen 2008; 2010], Internet discourse [Herring 2007; Schurina 2016].

This list can and should be continued. We see a possibility to highlight the following in the modern environment - political, administrative, legislation, military, pedagogic, religious, mystic, medical, business, advertising, sport, scientific, stage and media types of institutional discourse. Of course the list can be continued or changed. It is important to note that institutional discourse is historically variable — if some public institution disappears as a separate cultural system, the corresponding discourse is dissolved in close and related discourses. For example it is highly unlikely to find hunter's discourse in modern Russia [Karasik 2002: 279].

We may note that the above mentioned research is varied in its selection of particular objects (a particular type of discourse or its particular aspect, different types of discourse in comparison, significant discrepancies in their structure and development; function) as also of the research methodology and terminology. 
For example, R. Wodak gives a characteristic example of medical discourse, the basis of which is a diagram of the necessary communicative actions which are connected with admission of patients in one of Vienna's hospitals:

1) The patient is invited to the consulting room.

2) The patient undresses and lies down on the couch.

3) One of the physicians examines the patient.

4) The patient is dressed and returns to the hall.

5) A doctor who examined the patient dictates results to his colleague, then they exchange points of views or the doctor takes notes in his workbook.

6) The doctors invite the next patient.

In fact, this scheme is rarely put into practice, because along the way colleagues and doctors answer the phone, the nurse brings X-ray images of the previous patient; it is found that the patient's history is lost and the nurse goes to look for it, the electrocardiograph unit doesn't work, the next patient peers into the room, etc. All participants of the dialogue are accustomed to deviations and react to them normally [Wodak 1996: 55-56].

The book by T. Itskovich [Itskovich 2015] is devoted to systematization of religious discourse genres/styles on communicative-pragmatic and categorical-text basis, taking into account their cultural, historical and textual genesis. The author develops a unified deductive theoretical model for the study of these genres, including, on the one hand, a small system of ancient proto-genres (prayer, preaching, life), providing branches to a large number of modern genres, and on the other hand - theoretical understanding of text structure through the medium of the most important text categories and practical analysis of all proto-genres and modern genres of religious style by a single method based on textual genres structures, on material of about thousand complete religious texts of different genres: the canonical texts of the Gospel in Russian translations, texts of modern preaching as well as newspapers of Orthodox media and informal dialogues in groups of Orthodox parishes in the Internet.

The work by T. Itskovich is interesting due to its vivid deductive character: as the author notes, a deductive model (for example, genre typification) allows us to view the system of "branching". This deductive approach seems justified because, the search of genetic regularity cannot be different; secondly, the study of speech genres by itself almost always is deductive, at least in modern linguistics: statements as speech genres rule production and interpretation of texts; there are some specific genres (conditional $X, Y, Z$ ), as well as their types which are accepted deductively, though there is a gaping lacuna between these types and real linguistic analysis which needs to be filled in the future.

T.V. Itskovich suggests an external typology (the selection of genres, speech genre analysis) on the basis of the reverent tone and bi-directional religious communication, from the sacred to the profane world (sermon); from the profane to the sacred (prayers); religious communication in the framework of the profane world, focused on the transcendental reality (life).

The basis of the internal typology (text-categorical analysis of religious genres) is a model "topic (situational, subject-sacred, spiritual) $\sim$ composition $\sim$ chronotop $\sim$ 
tone", which the author tries to consistently and uniformly apply to all genres - the objects of his analysis: three protogenres as well as contemporary genres, even in cases where he investigates genres far removed from the general religious space like online (internet) communication (including expressive lexemes) or prayers genre, the most difficult of all genres amenable to analysis under this scheme.

The detailed study of political discourse and its genres is represented in the wellknown monograph by E. Sheigal in Russia and abroad (E.I. Sheigal: [2004]).

The speech genre research by E. Sheigal is very significant: the author has undertaken extremely profound and original typological research of genres in political discourse.

She highlights sets of main and peripheral genres for political discourse and its other types; she also shows how to divide the field of these genres, and reveals the line of convergence in political discourse with other types of discourses - scientific, legal, educational, religious, media discourse, as well as sports and games. It is shown that the centers of political discourse genres are those that correspond to the main purpose of political communications - the struggle for power: parliamentary debates, speeches of politicians, vote. In peripheral genres of political discourse, the function of struggle for power remains, but it is intertwined with the functions of other types of discourse. For example, an interview with a politologist includes elements of media, scientific and political discourse. At the junction between the discourse of the media and political discourse there are other genres, which can be placed on the scale viz a viz the actual political content: pamphlet, feuilleton, problematic political article written by a journalist, speaker columnist, editorial, report (from the Congress, rally, etc.), news article, interview with a politician, problem analytical article, debate (TV debates, discussions in the press), politician's speech, political document, (the Presidential decree, the text of the law, the communiqué).

E. Sheigal constructs typology of genres in political discourse on a number of grounds: in particular, ritual genres are limited by the nature of leading intention in political discourse (inaugural speech, commemorative speech, traditional radio report), orientation genres (party program, the Constitution, the President's message on the situation in the country, a summary report, a decree, agreement), agonal genres (slogan, advertising speech, electoral debates, parliamentary debates).

In addition, E. I. Sheigal has undertaken a special study of such genres of political discourse, as the inaugural address, slogan and political scandal as a narrative [same].

It should be noted that genre studying is significantly enriched not only by the mentioned work of E. Sheigal, but also by the fact, that the highlighted types of genres were studied by her followers from a number of other schools and on other material for example, on the material of journalistic and colloquial discourse.

Many researchers believe it is significant to contrast personality-oriented and status-oriented discourse.

The first case (in the case of a student-centered discourse - VD) in speech the communicants who know each other well, take part. They reveal to each other their inner world, in the second case, communication is reduced to a dialogue of representatives of a particular social group [Karasik 2002: 277]. 
Personal discourse is divided, according to V. Karasik, into two main varieties home (everyday) and existential discourse.

A distinctive feature of everyday discourse that V. Karasik believes in is the "short code" of communication (restricted code, according to B. Bernstein [Bernstein 1979: 164-167]), when people understand each other "at a glance".

The existential discourse is designed to find and experience real meanings; we are not talking about the obvious things, but of artistic and philosophical comprehension of the world. Here is an extract from "Karamazov Brothers":

"But what does it matter to us?" laughed Ivan. "We've time enough for our talk, for what brought us here. Why do you look so surprised?

Answer: why have we met here? To talk of my love for Katerina Ivanovna, of the old man and Dmitri? Offoreign travel? Of the fatal position of Russia? Of the Emperor Napoleon? Is that it?"

"No."

"Then you know what for. It's different for other people; but we in our green youth have to settle the eternal questions first of all. That's what we care about. Young Russia is talking about nothing but the eternal questions now. Just when the old folks are all taken up with practical questions. Why have you been looking [pg 256] at me in expectation for the last three months? To ask me, 'What do you believe, or don't you believe at all?' That's what your eyes have been meaning for these three months, haven't they?"

"Perhaps so," smiled Alyosha. "You are not laughing at me, now, Ivan?"

"Me laughing! I don't want to wound my little brother who has been watching me with such expectation for three months. Alyosha, look straight at me! Of course I am just such a little boy as you are, only not a novice. And what have Russian boys been doing up till now, some of them, I mean? In this stinking tavern, for instance, here, they meet and sit down in a corner. They've never met in their lives before and, when they go out of the tavern, they won't meet again for forty years. And what do they talk about in that momentary halt in the tavern? Of the eternal questions, of the existence of God and immortality. And those who do not believe in God talk of socialism or anarchism, of the transformation of all humanity on a new pattern, so that it all comes to the same, they're the same questions turned inside out. And masses, masses of the most original Russian boys do nothing but talk of the eternal questions! Isn't it so?"

Of course, the following genres are traditionally opposed: fiction and nonfiction, written and oral, monologue and dialogue texts/discourse/genres. We are not going to speak about widespread elaborate types of speech, we will note that linguists usually connect the essence of art-based communication and general opposition to others non-fiction varieties with discursive and recursive organization of speech, i.e., creative speech and standard use of the language [Juvan 2002; Dementyev, et al 2016]. It is noted that differentiation of art-based communication can take place on various grounds: it is a language game, different types of play behavior, including playing in the theater, artistic speech, literature in all its diversity of genres. Artistically-oriented communication overlaps with personally-oriented communication, as self-disclosure occurs mostly in creativity [Karasik 2002: 291-292]. 


\section{CONCLUSION}

The main task of current direction in discourse analysis is to find an adequate model of real dialogical speech communication. As shown in this article, TSG has good potentials for solving this problem.

Since the end of 80s SGT has already experienced a number of stages in its development, which can be summarized as follows: If at first (late 80 s - early 90s) speech genres were studied on the basis of methodology and terminology of speech act theory, the second stage consisted of overcoming disadvantages of the first stage.

Now SGT seems to be going through a new stage. It is connected, first of all, to bridge the gap between two previous trends - in fact the gap is artificial. Secondly, in understanding new, unclaimed ideas of Bakhtin (in genre studies "forward" often means "back to Bakhtin"); for example in modern genre studies representation of current speech pattern becomes especially important and a relevant issue for contemporary discourse analysis. M. Bakhtin gave initial impetus to studying actual processes of modern speech. He determined SG as "transmission belts from social history to the history of the language" [Bakhtin 1996: 165].

This aspect is being developed in several research groups:

- studying modernity: culture, communication, society - through the prism of SG ("Speech genres, selected by the language, are $<\ldots>$ one of the best keys to the culture of the society» [Wierzbicka 1983: 127]). Unfortunately, there are very few special works on this theme [Averincev 1986; Mustajoki 2013; Dementyev 2015]);

- studying SG through the prism of modernity: in fact, almost every study, claiming to be adequate, uses an integrated approach, at the same time it connects SG with more or less a broad cultural and historical context. We mention only a few most revealing works: [Abrahams 1974; Hanks 2000; Salimovsky 2002; Sedov 2016; Lakoff 2006; Intercession and others 2011]. In this regard, two aspects are studied often: appearing of new SG and new features and transformation of some traditional SG.

(C) Vadim. V. Dementyev, 2016

\section{REFERENCES}

Abrahams, R.D. (1974). Black Talking on the Streets. Explorations in the Ethnography of Speaking. Chapter IV: Speech Acts, Events, and Situations. N.Y.: Cambridge University Press.

Adamzik, K. (1995). Textsorten - Texttypologie. Eine kommentierte Bibliographie. Münster: Nodus Publ., 1995. (Studium Sprachwissenschaft. 12).

Austin, J.L. (1962). How to Do Things with words. Oxford: Oxford Univ. Press.

Averintsev, S.S. (1986). Istoricheskaya podvizhnost' kategorij zhanra: opyt periodizatsii [Historical mobility of category of the genre: the experience of periodization]. Moscow: Nauka, 104-116. (In Russian).

Balashova L.V. (2014). Russkaya metaforicheskaya sistema v razvitii: XI-XXI vv. [The Russian metaphorical system in development: 11th - 21st cent.]. Moscow: Rukopisnye pamiatniki Drevnei Rusi: Znak. (In Russian).

Bakhtin, M.M. (1996). Problema rechevykh zhanrov [The problem of speech genres]. Moscow: Yazyki Russkoi Kul'tury, 159-206. (In Russian). 
Benveniste, E. (1979). Problemes de linguistique generale. P.: Gallimard, 1974. Vol. 1-2.

Bernstein, B. Social Class, Language and Socialization // Language and Social Context: Selected Readings. Harmondsworth: Penguin, 1979.

Bhatia, Vijay K. (2002). Applied genre analysis: a multi-perspective model // Ibérica, 4, 3-19.

Bobyreva, E. V. (2007). Religioznyi diskurs: tsennosti, zhanry, strategii (na materiale pravoslavnogo veroucheniya) [Religious discourse: values, genres, strategies (based on the Orthodox Christianity)]. Volgograd: Peremena. (In Russian).

Bogin, G.I. (1997). Rechevoy zhanr kak sredstvo individualizatsii [Speech genres as means of individualization]. Saratov: Kolledj. (In Russian).

Borisova, I.N. (2001). Russkiy razgovornyi dialog: struktura i dinamika [Russian colloqial dialogue: structure and dynamics]. Yekaterinburg: Ural Univ. Publ. (In Russian).

Dementyev, V.V. (2009). Russian Anekdots of 1970s: on the Material of the Soviet Humorous Magazine "Krokodil". Russian Journal of Communication, Vol. 2, Nos. 3/4. Special Issue: The Russian anekdot as cultural genre, discourse and performance.

Dementyev, V.V., Balashova, L.V., Stepanova N.B., Baykulova A.N. (2014). Linguistic aspect of speech genres. Journal of Language and Literature. 5( 4), 288-291.

Dementyev V.V., Balashova L.V., Stepanova N.B., Shapovalova N.G. (2016). Language - genre creativity: linguistic aspects of the problem. Journal of Language and Literature. 7.(1), 142-145.

Dementyev, V.V. (2010). Teoriya rechevykh zhanrov [A theory of speech genres]. Moscow: Znak. (Kommunikativnye strategii kul'tury). (In Russian).

Dementyev, V.V. (2015). Teoriya rechevykh zhanrov i aktual'nye protsessy sovremennoj rechi [The theory of speech genres and actual processes of the modern speech]. Moscow: Voprosy yazykoznaniya, 6 (7-107). (In Russian).

Dementyev, V.V. (2016). Nekotoryye metodologicheskiye printsipy izucheniya rechezhanrovykh zaimstvovanii [Some Methodological Principles of Study on Borrowing Speech Genres]. Vestnik Rossiyskogo universiteta druzhby narodov. Seriya Lingvistika. 20 (1), 7-24. (In Russian).

Dijk, T.A. van. (1985). Handbook of discourse analysis. V. 1-4. L.: Academic Press.

Dönninghaus, S. (2001). Sprechakt und Kommunikationsgenre. (Theoretische Aspekte der sprachlichen Interaktion). Beiträge der Europäischen Slavistischen Linguistik (PolySlav). Bd. 4. München, 69-79.

Dönninghaus, S. (2005). Die Vagheit der Sprache: Begriffsgeschichte und Funktionsbeschreibung anhand der tschechischen Wissenschaftssprache (Slavistische Studienbucher. Neue Folge). Wiesbaden: Harrassowitz.

Dolinin, K.A. (1999) Rechevye zhanry kak sredstvo organizatsii social'nogo vzaimodeystviya [Speech genres as means of organization of social interaction]. Saratov: Zhanry rechi (2), 7-13. (In Russian).

Dubrovskaya, T.V. (2014). Sudebnyi diskurs kak kul'turnyi fenomen: natsional'no-kul'turnye osobennosti rechi sudei (na materiale russkikh, anglijskikh i avstralijskikh sudebnykh zasedaniy) [Legal discourse as a cultural phenomenon based on English, Russian and Australian court hearings]. Moscow: Voprosy yazykoznaiya (2), 76-88. (In Russian).

Duskaeva, L.R. (2012). Dialogicheskaya priroda gazetnykh rechevykh zhanrov [Dialogical nature of the newspaper speech genres]. St. Petersburg: St. Petersburg State Univ. (In Russian).

Dymarskiy, M.Ya. (2015). Model' vyskazyvaniya i rechevye zhanry (na materiale kontroptativnykh infinitivnykh vyskazyvaniy [The model o statement and speech genres]. Moscow: Institut russkogo yazyka im. V.V. Vinogradova, 54-56. (In Russian).

Fedosyuk, M.YU. (1997). Nereshennye voprosy teorii rechevyh zhanrov [Unsolved problems in the theory of speech genres]. Moscow: Voprosy yazykoznaniya (5), 102-120 (In Russian). 
Fillmore, Ch. (1976). Nyt need for a frame semantics within linguistics. Statist. Meth. Linguist. Vol. 1.

Fix U. (2008). Texte und Textsorten — sprachliche, kommunikative und kulturelle Phänomene. Berlin: Frank \& Timme GmbH.

Gajda St. (1991). Gatunki wypowiedzi potocznyc. Język potoczny jako przedmiot badań językoznawczych. Z. Adamiszyn: Opole, 67-74.

Gatunki mowy (2004-2007). Gatunki mowy i ich ewolucja. Pod red. Danuty Ostaszewskiej. T. 1. Mowy piękno wielorakie. Katowice: Wydaw. Uniwersytetu Śląskiego, 2000; T. 2. Tekst a gatunek. Katowice: Wydaw. Uniwersytetu Śląskiego, 2004; T. 3. Tekst a odmiany funkcjonalne. Katowice: Wydaw. Uniwersytetu Śląskiego.

Goddard, C. \& Wierzbicka, A. (1997). Discourse and Culture // Teun A. van Dijk (ed.) Discourse as Social Interaction / Discourse Studies: A Multidisciplinary Introduction. L.: Sage, Vol. 2, $231-259$.

Goldin, V.E., Sirotinina, O.B. Vnutrinatsionalnye rechevye kultury i ikh vzaimodeistvie [Sub-national speech cultures and their interactions]. Saratov: Izd-vo Sarat. gos. univers. (In Russian).

Hanks W.F. (2000). Dialogic conversions and the field of missionary discourse in Colonial Yucatan. Les Rituels du Dialogue. A. Monod Becquelin \& Philippe Erikson (ed.). Nanterre: Société d'Ethnologie, 235-254.

Herring, S.C. (2007). A Faceted Classification Scheme for Computer-Mediated Discourse. Language@Internet, 4. Article 1 [Retrieved April 26, 2009].

Itskovich, T.V. (2015). Kategorial'no-tekstovaya specifika sovremennoy pravoslavnoy propovedi [Categorical and textual specificity of modern Orthodox preaching]. Ekaterinburg: ID Azhur. (In Russian).

Juvan, M., (2002). Literariness as a culturally based feature. In Stylistyka XI. Opole, 9-29.

Karasik, V.I. (2002). Yazykovoj krug: lichnost', kontsepty, diskurs [Language circle: personality, concepts, discourse]. Volgograd: Peremena. (In Russian).

Karzenkova, E.P., Salimovskiy, V.A. (2005). K ehksplikatsii ponyatiya kommunikativnoy kategorii [To the explication of communicative category's notion]. Perm': Izd-vo Perm. un-ta, 98-104. (In Russian).

Kitaygorodskaya, M.V., Rozanova, N.N. (1999). Rech' moskvichey. Kommunikativno-kul'turologicheskiy aspekt [Speech of Muscovites. Communicative and cultural aspect]. Moscow: Russkie slovari. (In Russian).

Kozhina, M.N. (1999). Rechevoy zhanr i rechevoy akt (nekotorye aspekty problemy) [Speech genre and speech act (some aspects of the problem)]. Zhanry rechi. No. 2. Saratov: Zhanry rechi (2), 52-61. (In Russian).

Krasnyh, V.V. (2015). ZHanry rechi skvoz' prizmu mnogomernosti bytiya Cheloveka govoryashchego [Speech genres through the prism of the multidimensionality of Homo Loquens]. Moscow: Zhanry rechi (1), 9-14. (In Russian).

Lakoff, R. (2001). The Language war. Berkeley; Los Angeles; London: University of California Press.

Lakoff, R. (2006). Identity à la carte: you are what you eat. Discourse and Identity. Anna DeFina, Deborah Schiffrin and Michael Bamberg (ed.). Cambridge: Cambridge University Press, 142-165.

Manes J. (1983). Compliments: A Mirror of Cultural Values // Sociolinguistics and Language Acquisition. N. Wolfson, E. Judd (Eds.). Rowley.

Matveeva, T.V. (1995). K lingvisticheskoy teorii zhanra [By linguistic theory genre]. Kiev: Collegium (1-2). (In Russian).

Minsky, M. (1975). A Framework for Representing Knowledge. MIT-AI Laboratory Memo 306, June. Reprinted in The Psychology of Computer Vision, P. Winston (Ed.), McGraw-Hill. 
Mkrtychyan, S.V. (2015). Rechevoy zhanr: o edinitsah strukturirovaniya produkta rechevoy deyatel'nosti [Speech genre: the unit of product structuring off speech activity]. Saratov: Zhanry rechi. (In Russian).

Mustajoki, A. (2013). Title Risks of miscommunication in various speech genres. Understanding by Communication. E. Borisova \& O. Souleimanova (ed.). Cambridge Scholars Publishing. Cambridge, $33-53$.

Oleshkov, M.Yu. (2012). Pedagogicheskiy diskurs [Pedagogical discourse]. Nizhni Tagil: Nizhni Tagil State Social-Pedagogical Academy. (In Russian).

Palashevskaya, I.V. (2012). Sudebnyi diskurs: funktsii, struktura, narrativnost' [Legal discourse: functions, structure, narrativity]. Volgograd: Volgograd State Pedagogical Univ. (In Russian).

Peeters, B. (2009). Language and cultural values: the ethnolinguistic pathways model. Flinders University Languages Group Online Review. 4 (1), 90-117.

Pokrovskaya, E.A., Dudkina, N.V., Kudinova, E.V. (2011). Rechevye zhanry v dialoge kul'tur [Speech genres in the dialogue of cultures]. Rostov-na-Donu: Foundation. (In Russian).

Ponomarenko, E.A. (2011). Rechevye zhanry v meditsinskom diskurse (v proizvedeniyakh russkikh pisateley-vrachey) [Speech genres in the medical discourse (in the texts of Russian doctor writers]. Simferopol': Dombrovsky Writers' House. (In Russian).

Salimovskiy, V.A. (2002). Zhanry rechi v funktsional'no-stilisticheskom osveshhenii (nauchnyy akademicheskiy tekst) [Speech genres from the functional-stylistic perspective (academic scientific text)]. Perm': Izd-vo Perm. un-ta. (In Russian).

Searle, J.R. (1983). Intentionality: An Essay in the Philosophy of Mind. Cambridge: Cambridge University Press.

Sedov, K.F. (2016). Obshchaya i antropocentricheskaya lingvistika [General and anthropological linguistics]. Moscow: Yazyki slavyanskih cultur. (In Russian).

Shevchenko, I.S. (2015). Koncept kommunikativnogo povedeniya i zhanr [Concept of communicative behavior and genre]. Saratov: Zhanry rechi (1), 23-24. (In Russian).

Sheigal, E.I. (2004). Semiotika politicheskogo diskursa [Semiotics of political discourse]. Moscow: Gnozis. (In Russian).

Sherstyanykh, I.V. (2013) Teoriya rechevyh zhanrov [The theory of speech genres]. Moscow: Flinta Nauka. (In Russian).

Shmeleva, T.V. (1997). Model' rechevogo zhanra [Model of speech genre]. Saratov: Kolledj (1), 88-89. (In Russian).

Schurina, Y.V. (2016). Zhanrovoe svoeobrazie social'noj seti Instagram [Genre individuality of Instagram social net]. Saratov: Zhanry rechi (1), 156-168. (In Russian).

Sirotinina, O.B. (1999). Nekotorye razmyshleniya po povodu terminov "rechevoj zhanr" $i$ "ritoricheskij zhanr" [Some reflections concerning the term "speech genre" and "rhetorical genre"]. Saratov: Kolledj, 26-31. (In Russian).

Slyshkin, G.G. (2005). Rechevoj zhanr: perspektivy konceptologicheskogo analiza [Speech genre: perspectives of conceptological analysis]. Saratov: IZ Nauka: Zhanry rechi, (4), 34 49. (In Russian).

Small talk (2000). Small talk. J. Coupland (ed.). Harlow: Longman.

Swales, J.M. (1990). Genre Analysis: English in Academic and Research Settings. Cambridge: Cambridge University Press.

Tannen D. (2008). «We've Never Been Close, We're Very Different»: Three Narrative Types in Sister Discourse. Narrative Inquiry. 18:2, 206-229.

Tannen, D. (2010). Abduction and identity in family interaction: Ventriloquizing as indirectness. Journal of Pragmatics. 42, 307-316. 
Thomas, J. (1985). Cross-cultural discourse as "unequal encounter": towards a pragmatic analysis. Applied Linguistics, 5.

Wierzbicka, A. (1983). Genry mowy // Tekst i zdanie. Zbiór studiów / Red. T. Dobrzyńska, E. Janus. Wroclaw itd.: PAN, 125-137.

Wierzbicka, A. (1991). Cross-Cultural Pragmatics: The semantics of human interaction. Berlin: Mouton de Gruyter.

Wierzbicka, A. (2006). Anglo scripts against 'putting pressure' on other people and their linguistic manifestations. Cliff Goddard (ed.) Ethnopragmatics: Understanding Discourse in Cultural Context. Mouton de Gruyter, $31-63$.

Witosz, B. (2005). Genologia lingwistyczna. Zarys problematyki. Katowice: Wydawnictwo Uniwersytetu Śląskiego.

Wodak, R. (1996). Disorders of discourse. London and New York: Longman.

Wojtak, M. (2011). Wspótczesne modlitewniki w oczach językoznawcy. Studium genologiczne. Tarnów: Biblos.

\author{
Article history: \\ Received: 15 September 2016 \\ Revised: 28 September 2016 \\ Accepted: 02 October 2016
}

\title{
For citation:
}

Dementyev, V. (2016). Speech Genres and Discourse: Genres Study in Discourse Analysis Paradigm. Russian Journal of Linguistics, 20 (4), 103-121.

\section{Bio Note:}

Vadim Dementyev, Doctor of Philology, Professor of the Department of Language Theory and History, and Applied Linguistics of Chernyshevsky Saratov State University, member of the editorial board of Russian Journal of Linguistics (Peoples' Friendship University of Russia, Moscow). Research interests: the theory of discourse, communicative axiology, theory of speech genres. Contact information: e-mail: dementevvv@yandex.ru.

\section{ЖАНРЫ РЕЧИ И ДИСКУРС: МЕСТО ЖАНРОВЕДЧЕСКИХ ИССЛЕДОВАНИЙ В ПАРАДИГМЕ ДИСКУРС-АНАЛИЗА}

\author{
В.В. Дементьев \\ Саратовский государственный университет им. Н.Г. Чернышевского \\ 410012, г. Саратов, Россия, ул. Астраханская, д. 83
}

Статья посвящена месту исследований по речевым жанрам в парадигме дискурс-анализа. Обсуждаются направления дискурс-анализа, имеющие общие с теорией речевых жанров проблемы, категориальный аппарат или набор базовых единиц, а также использующие речежанровую методику 
для решения своих проблем. Показано, что главной проблемой, объединяющей дискурс-анализ и теорию речевых жанров, является структурирование и параметризация речевой коммуникации, а тем самым - поиск базовых моделей данного структурирования, организующих как порождение речи, так и ее интерпретацию. В этой связи обсуждаются единицы дискурса, место их по отношению к речевым жанрам и в общем околожанровом пространстве речи. Анализируются коммуникативный и когнитивный аспекты данных единиц, строятся цепочки, звенья которых соответствуют компонентам коммуникативных концептов, имеющих четкое композиционно-тематически-стилистическое содержание (зафиксированные в языке имена данных концептов являются или непосредственно именами речевых жанров, или их компонентов, или отражают оценочное отношение к ним в рамках данной культуры): стандартная структура коммуникативного концепта представляет собой цепочку «действие/акт процесс/манера $\sim$ роль/тип жанр $\sim$ коммуникативная тональность», при этом в большинстве цепочек речевые жанры являются главными компонентами. Много внимания уделяется дискурсивной классификации речевых жанров: обсуждаются жанры в разных типах дискурса.

Ключевые слова: теория речевых жанров, дискурс-анализ, параметризация речи, классификация, коммуникативные концепты

\section{История статьи:}

Дата поступления в редакцию: 15 сентября 2016

Дата принятия к печати: 02 октября 2016

\section{Для цитирования:}

Дементьев В.В. Жанры речи и дискурс: место жанроведческих исследований в парадигме дискурс-анализа // Вестник Российского университета дружбы народов. Серия: Лингвистика. 2016. T. 20. № 4. С. 103-121.

\section{Сведения об авторах:}

Дементьев Вадим Викторович, доктор филологических наук, профессор, профессор кафедры теории, истории языка и прикладной лингвистики Саратовского национального исследовательского государственного университета имени Н.Г. Чернышевского. Сфера научных интересов: теория дискурса, коммуникативная аксиология, теория речевых жанров. Контактная информация: e-mail: dementevvv@yandex.ru 